Semina $\square \quad$ Nr 16

Scientiarum 2017

s. $255-273$

DOI: http://dx.doi.org/10.15633/ss.2495

Kamil Trombik

\title{
Użyteczność metod logiki nieformalnej \\ w badaniu argumentów w dyskusjach między teistami a ateistami
}

Gdyby w naturze ludzkiej nie było złego, gdybyśmy byli zupełnie uczciwi przy każdej wymianie zdań, wówczas staralibyśmy się dotrzeć jedynie do prawdy, nie dbając o to, czy racja okaże się po stronie poglądu wygłoszonego początkowo przez nas samych, czy też przez naszego przeciwnika. Ten ostatni wzgląd byłby dla nas zupełnie obojętnym, albo przynajmniej nie nadawalibyśmy mu pierwszorzędnego znaczenia. Dziś zaś, przeciwnie, jest to rzecz najważniejsza ${ }^{1}$.

Przypuszczać można, że gdyby Artur Schopenhauer żył w naszych czasach, nie zmieniłby zdania na temat ludzkiej natury. Biorąc pod uwagę wartość merytoryczną licznych dyskusji, które prowadzi się dziś w polityce, mediach społecznościowych, na salach sądowych, a nierzadko nawet w szkołach wyższych, trudno o optymizm. Choć komunikujemy się przy pomocy coraz bardziej różnorodnych i wyrafinowanych form, to jakość wypowiedzi argumentacyjnych, którymi posługujemy się z myślą o przekonaniu drugiej osoby do modyfikacji jej przekonań, budzić może zastrzeżenia. Wydaje się, że problem ten obecny jest również w dyskusjach, które toczą się między teistami a ateistami. Czy Bóg istnieje? Jaka jest rola i znaczenie religii

1 A. Schopenhauer, Erystyka, czyli sztuka prowadzenia sporów, tłum. J. Lorenowicz, Kraków 2010, s. 10. 
w rozwoju kultury zachodniej? Czy ludzie religijni są nietolerancyjni? Czy ateiści są moralnymi relatywistami? To tylko niektóre z pytań, z którymi mierzą się dyskutanci w toczonych sporach i polemikach ${ }^{2}$.

Argumentacja stosowana w dyskusjach między teistami a ateistami bywa bardzo zróżnicowana. Z racji tego, iż perswazyjna funkcja języka odgrywa w ludzkiej kulturze podstawową rolę, od najmłodszych lat uczymy się sztuki budowania różnych argumentów (np. ad verecundiam $^{3}$, ad misericordiam ${ }^{4}$ ), wykorzystując tę umiejętność przy nadarzających się okazjach. W artykule tym postawiono tezę, iż metody stosowane w logice nieformalnej (zwanej niekiedy teoria argumentacji lub teorią krytycznego myślenia) ${ }^{5}$ mogłyby okazać się pomocne w badaniu argumentów, które pojawiają się w dyskusjach między teistami a ateistami. Wykorzystywana w tym nurcie logiki analiza argumentów dokonuje się w kilku etapach, przede wszystkim poprzez standaryzację argumentu ${ }^{6}$, odwzorowanie relacji uzasadniania między przesłankami a konkluzja (oraz pomiędzy samymi przesłankami) i zbadanie poprawności materialnej argumentu oraz natury związku przesłanek z konkluzją ${ }^{7}$. Dzięki wykorzystaniu zdobyczy psychologii

2 Przyjęto w tej pracy, że argumenty w takich dyskusjach dotyczą nie tylko kwestii istnienia/nieistnienia Boga, ale także związanego z podzielanym światopoglądem stylu życia, praktyk etycznych itp.

3 Tzw. argument $\mathrm{z}$ autorytetu, choć ściślej rzecz ujmując, argumentum ad verecundiam oznacza argumentację odwołującą się do nieśmiałości. Tego rodzaju technika komunikacyjno-poznawcza jest jednak tradycyjnie wiązana z argumentacją odwołujacca się do autorytetu, o czym piszą m.in. M. Koszowy, K. Budzyńska, Strategie retoryczne, techniki komunikacyjno-poznawcze, błędy i sofizmaty, Warszawa 2015, s. 140; K. Szymanek, Sztuka argumentacji. Stownik terminologiczny, Warszawa 2004, s. 61-62.

4 Tzw. argument odwołujący się do współczucia.

5 Zob. M. Tokarz, Argumentacja, perswazja, manipulacja. Wykłady z teorii komunikacji, Gdańsk 2006, s. 125.

6 Przez standaryzację argumentu rozumie się uporządkowanie elementów wypowiedzi argumentacyjnej, tzn. wyodrębnienie z niej konkluzji i przesłanek (także tych niejawnych) w postaci samodzielnych zdań. Podczas standaryzacji pomijamy te elementy wypowiedzi, które naszym zdaniem nie sa istotne dla przeprowadzonej argumentacji (m.in. elementy ekspresywne, wyrażenia mętne), ewentualnie zastępujemy je zrozumiałymi i neutralnymi odpowiednikami.

7 Przez przesłankę należy rozumieć zdanie, na podstawie którego prowadzi się rozumowanie, natomiast konkluzją wnioskowania jest zdanie, którego prawdziwość orzeka się na podstawie wcześniejszego uznania przesłanek. 
społecznej akcentuje się tutaj również rolę mechanizmów psychicznych, które wpływają na dokonywaną ocenę argumentu i jego konfrontację z innymi posiadanymi przez nas przekonaniami. Wykorzystanie tych wszystkich elementów w badaniu wypowiedzi argumentacyjnych mogłoby obnażyć merytoryczną wartość wielu powszechnie podzielanych przekonań na temat teizmu (i teistów) oraz ateizmu (i ateistów). Użyteczność zastosowania metod logiki nieformalnej zobrazowana zostanie także kilkoma przykładami, przy czym należy nadmienić, że przywołane argumenty nie wyrażają poglądów autora, nie mają też funkcji perswazyjnej, lecz wykorzystywane są wyłącznie jako przykładowe wypowiedzi na rzecz podejmowanej analizy.

\section{Sposoby analizy argumentów}

Logika nieformalna narodziła się w drugiej połowie XX wieku, w Stanach Zjednoczonych i Kanadzie ${ }^{8}$ (choć jej ideowe korzenie sięgaja przynajmniej czasów starożytnej Grecji). Głównym zadaniem, które stawiają sobie przedstawiciele tego nurtu, jest analiza i ocena argumentów formułowanych w języku potocznym ${ }^{9}$. Powód powstania logiki nieformalnej wydaje się więc zupełnie pragmatyczny: chodzi o dostarczenie narzędzi do rozwiązywania praktycznych problemów, związanych z codziennymi rozumowaniami i argumentami, które pojawiać się mogą np. w przestrzeni publicznej. Wychodzi się

8 Zob. L. Rossetti, Raport o „logice nieformalnej”, w: Między prawda i norma a błędem, red. E. Żarnecka-Biały, Kraków 1997, s. 238. Na temat polskiej szkoły logiki nieformalnej zob. K. Budzyńska et al., The Polish School of Argumentation: A Manifesto, „Argumentation” 28 (2014), s. 267-282. W ostatnim czasie w naszym kraju logikę nieformalną na większą skalę uprawia się m.in. na Uniwersytecie Śląskim w Katowicach, w kręgu uczniów prof. Marka Tokarza (Andrzej Wójcik, Krzysztof Szymanek, Krzysztof A. Wieczorek). Zob. np. K. Szymanek, Sztuka argumentacji..., Warszawa 2004; K. Szymanek, A. Wójcik, K. A. Wieczorek, Sztuka argumentacji. Ćwiczenia w badaniu argumentów, Warszawa 2005; K. Szymanek, Argument z podobieństwa, Katowice 2008; K. A. Wieczorek, Argumenty równi pochyłej. Analiza z perspektywy logiki nieformalnej, Katowice 2013.

9 Zob. J. A. Blair, Informal Logic and Logic, „Studies in Logic, Grammar and Rhetoric" 16 (2009) no. 29, s. 47. 
tutaj z założenia, że kryteria logiki formalnej sa zbyt wygórowane do oceny potocznych rozumowań. Dla logika ideałem sa zwykle rozumowania dedukcyjne, w których wniosek wynika logicznie z koniunkcji przesłanek. Wnioskując dedukcyjnie, „wnioskujemy zawsze w sposób niezawodny, albowiem - zgodnie z definicja - wnioskujemy dedukcyjnie, gdy wnioskujemy wedle jakiegoś schematu logicznego, a więc wedle schematu formalnego i niezawodnego" ${ }^{10}$. Wniosek uzyskany za pomoca rozumowania dedukcyjnego jest tak samo pewny jak przesłanki, z których został wyprowadzony (prawdziwość wniosku zostaje zagwarantowana prawdziwościa przesłanek oraz faktem, że wnioskowanie jest oparte na regule logicznej). Nie uwzględnia się więc rozwiązań pośrednich między wypowiedziami całkowicie poprawnymi a całkowicie błędnymi. W logice nieformalnej zwraca się natomiast uwagę na to, iż potoczne rozumowania moga posiadać mniejszy lub większy stopień uzasadnienia. Problemy z przełożeniem argumentów wypowiadanych w języku potocznym na język sformalizowany, a zwłaszcza trudność z zastosowaniem kryterium wynikania logicznego do oceny wartości argumentu skłoniła ostatecznie wielu uczonych do porzucenia ambicji tradycyjnej logiki. Różnice między argumentami słabymi i lepszymi wykazywać bowiem można przy zastosowaniu nieco bardziej wyrafinowanych, niesformalizowanych metod.

Według Krzysztofa Szymanka:

(...) z argumentem mamy do czynienia wtedy, gdy jako uzasadnienie poglądu T przedstawiane sa jakieś zdania P1, P2, ..., Pn; zdania te nazywa się przesłankami, zaś zdanie $\mathrm{T}$ - konkluzją argumentu ${ }^{11}$.

W tym sensie argumentem będzie np. wypowiedź: „Żyjemy w państwie świeckim. Krzyż nie powinien zatem wisieć w sali sejmowej”. Pierwsze zdanie jest tutaj przesłanką dla zdania drugiego, będącego konkluzja. Wyodrębnianie z wypowiedzi argumentacyjnej przesłanek oraz konkluzji jest tutaj przykładem standaryzacji argumentu.

10 K. Ajdukiewicz, Zarys logiki, Warszawa 1955, s. 160.

11 K. Szymanek, Sztuka argumentacji..., dz. cyt., s. 37. 
Na tym etapie należy zachować ostrożność, często bowiem stajemy przed koniecznością uzupełniania oryginalnej wypowiedzi o elementy pominięte przez nadawcę komunikatu. W powyższym przykładzie autor wypowiedzi zakładał zapewne w domyśle, że: „W państwie świeckim nie powinniśmy eksponować symboli religijnych w miejscach publicznych"12. Standaryzacja powyższego argumentu - po uwzględnieniu ukrytej przesłanki - wyglądałaby zatem następująco:

( $\left.\mathrm{P}_{1}\right)$ Żyjemy w państwie świeckim.

$\left(\mathrm{P}_{2}\right) \mathrm{W}$ państwie świeckim nie powinniśmy eksponować symboli religijnych w miejscach publicznych.

(K) Krzyż nie powinien zatem wisieć w sali sejmowej.

W kolejnym etapie badań podejmuje się pytanie o sposób, w jaki zachodzi relacja uzasadniania między przesłankami a konkluzja oraz między samymi przesłankami w badanych argumentach. Pomocne w tym przypadku może okazać się sporządzenie tzw. diagramu argumentu, czyli graficznego odwzorowania zachodzacych w wypowiedzi argumentacyjnej relacji między poszczególnymi jej elementami. Jeśli mamy do czynienia z tzw. argumentem prostym, wówczas każda z przesłanek wykorzystywana jest tylko i wyłącznie do uzasadnienia konkluzji, natomiast w argumentach złożonych co najmniej jedna przesłanka wykorzystywana jest do uzasadnienia innych przesłanek, tworząc tzw. podargument pośredni danego argumentu. W świetle tego jako argument prosty można by rozumieć wypowiedź: „Biblia myli się co do wizji początku świata, a historyczny Jezus nie uważał się za Boga. Dlatego uważam, że chrze-

12 W 2011 roku posłowie Klubu Parlamentarnego Ruch Palikota wystapili z wnioskiem do ówczesnego marszałka sejmu o wydanie zarządzenia nakazującego usunięcie krzyża. W dokumencie autorzy napisali, iż „Rzeczpospolita Polska jest państwem świeckim, którego władze publiczne, w tym władza ustawodawcza, powinny zachowywać bezstronność w sprawach przekonań religijnych, światopoglądowych i filozoficznych”. Źródło: Ruch Palikota składa wniosek o usunięcie krzyża z sali sejmowej, https://ekai.pl/ruch-palikota-sklada-wniosek-o-usuniecie-krzyza-z-sali-sejmowej (22.11.2017). 
ścijaństwo opiera się na kłamstwach”. Standaryzacja argumentu wyglądałaby następująco:

$\left(\mathrm{P}_{1}\right)$ Biblia myli się co do wizji początku świata.

$\left(\mathrm{P}_{2}\right)$ Historyczny Jezus nie uważał się za Boga.

(K) Dlatego chrześcijaństwo opiera się na kłamstwach.

Graficzne przedstawienie tego argumentu w postaci diagramu prezentuje się następująco:

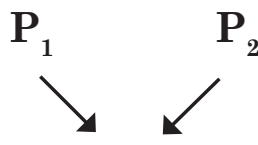

$\mathbf{K}$

Pierwsze dwa zdania powyższej wypowiedzi argumentacyjnej, tj. przesłanki $\mathrm{P}_{1}$ oraz $\mathrm{P}_{2}$, tylko i wyłącznie wspierają konkluzję (i to w sposób niezależny), a więc mamy tutaj do czynienia z argumentem prostym.

Z kolei argumentem złożonym będzie np. wypowiedź (przedstawiona po standaryzacji):

$\left(\mathrm{P}_{1}\right)$ Według statystyk ateiści częściej popełniają samobójstwa niż ludzie wierzący w Boga.

$\left(\mathrm{P}_{2}\right)$ Ateizm odbiera życiu sens i cel.

$\left(\mathrm{P}_{3}\right)$ Ateizm nie sprzyja szczęśliwemu życiu.

$\left(\mathrm{P}_{4}\right)$ Nie warto zawracać sobie głowy tym, co nie sprzyja szczęśliwemu życiu.

(K) Nie warto być ateistą.

W powyższej wypowiedzi pierwsza i druga przesłanka wspieraja przesłankę trzecią (traktując ją jako konkluzję ${ }^{13}$ ), która z kolei wy-

13 Jest to podargument pośredni dla wypowiedzi argumentacyjnej, której ostateczna konkluzja jest zdanie Nie warto być ateista. 
stępuje z przesłanką czwartą jako uzasadnienie dla konkluzji całej wypowiedzi. Diagram tego argumentu jest następujący:

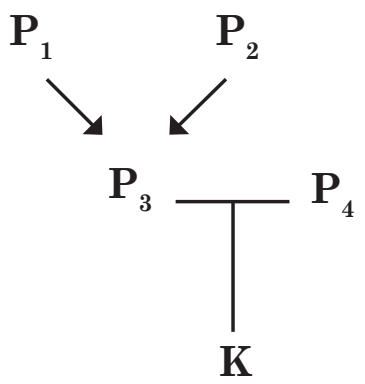

Niezależnie od tego, czy mamy do czynienia z argumentem prostym, czy złożonym, to od odbiorcy wypowiedzi zależeć będzie, czy zaakceptuje konkluzję na podstawie zaproponowanych przesłanek. Najważniejszymi kwestiami do rozważenia są tutaj „poprawność materialna argumentu, czyli prawdziwość użytych w nim przesłanek, a także logiczny związek przesłanek z konkluzją"14, a więc stopień, w jakim przesłanki uzasadniaja konkluzję. Problem polega jednak na tym, że w prowadzonych na żywo dyskusjach najczęściej trudno jest ustalać ad hoc wiarygodność przesłanek oraz stopień, w jakim wspierają one wniosek; trudność ta uwidacznia się zwłaszcza wówczas, gdy argument jest złożony, jak widać na powyższym diagramie. Często ulegamy też świadomie zaplanowanym działaniom perswazyjnym ${ }^{15}$. Podlegamy ponadto różnym uwarunkowaniom psychologicznym o ewolucyjnym rodowodzie ${ }^{16}$. Silne emocje, dysonans poznawczy, skłonność do myślenia życzeniowego, błędy w rozumowaniach dotyczących przyczyn, uleganie tzw. efektowi „aureoli” czy potwierdzenia, stosowanie heurystyk dostępności, preferowanie pew-

14 K. Szymanek, Sztuka argumentacji..., dz. cyt., s. 44.

15 Na temat niektórych narzędzi wpływu (m.in. reguły wzajemności, społecznego dowodu słuszności, autorytetu) zob. R. B. Cialdini, Wywieranie wpływu na ludzi. Teoria i praktyka, tłum. B. Wojcieszke, Gdańsk 2013.

16 Zob. np. D. M. Buss, Psychologia ewolucyjna, tłum. M. Orski, Gdańsk 2001, s. 396-405; P. Gardenfors, Jak Homo stał się sapiens. O ewolucji myślenia, tłum. T. Pańkowski, Warszawa 2010. 
ności zamiast wątpliwości, uleganie złudzeniu zrozumienia i wiele innych - te wszystkie mechanizmy moga utrudniać nam nie tylko formułowanie rzetelnych argumentów, ale także okazać się przeszkodą w dokonaniu merytorycznej oceny wypowiedzi oponenta ${ }^{17}$.

Majacc to wszystko na uwadze, rozsądnie byłoby prowadzić dyskusje w duchu skromności, otwarcia na krytykę i powściagania wygórowanych ambicji perswazyjnych. Sugestia ta mogłaby okazać się szczególnie pomocna w sporach między teistami a ateistami. Wśród dyskutujących na temat Boga, religii i wiary obok silnych emocji często pojawia się przeświadczenie o wyższości własnego stanowiska nad stanowiskiem przeciwnika. Tymczasem nawet nabycie umiejętności oceny cudzych argumentów nie sprawia, że stajemy się już specjalistami w budowaniu własnych. Czy jednak za każdym razem o tym pamiętamy?

\section{Zastosowanie narzędzi logiki nieformalnej w dyskusjach między teistami i ateistami}

Wykorzystanie metod analizy argumentów, które wypracowała logika nieformalna, może służyć w dokonywaniu oceny wielu powszechnie podzielanych przekonań pojawiajacych się w sporach między teistami a ateistami. W ocenie tych argumentów logika nieformalna stawia na kryterium praktyczne. Uważa się, że argumentacja jest poprawna, jeśli „(a) wszystkie użyte w niej przesłanki są akceptowalne oraz (b) dowodzona teza znajduje w tych przesłankach dostateczne uzasadnienie"18. Szczegółowe sposoby oceniania argumentów bywają zróżnicowane ${ }^{19}$. Interesująco wypada w tym kontekście

17 Zob. np. D. Kahneman, Pułapki myślenia. O myśleniu szybkim i wolnym, tłum. P. Szymczak, Poznań 2012; D. J. Hand, Zasada nieprawdopodobieństwa. Dlaczego codziennie zdarzaja się cuda i zbiegi okoliczności, tłum. J. Winiarski, Warszawa 2015; C. Tavris, E. Aronson, Bładzq wszyscy (ale nie ja), tłum. A. Nowak, Sopot 2008; M. Tokarz, Argumentacja, perswazja..., dz. cyt., s. 293-326.

18 M. Tokarz, Argumentacja, perswazja..., dz. cyt., s. 139.

19 Ciekawą metodę oceny siły argumentu zaproponował M. Tokarz, Argumentacja, perswazja..., dz. cyt., s. 142-147. 
np. metoda zaproponowana przez Krzysztofa Szymanka, Andrzeja S. Wójcika i Krzysztofa A. Wieczorka, ukierunkowana zwłaszcza na zbadanie mocy, z jaką przesłanki argumentu wspierają jego konkluzję ${ }^{20}$.

Zastosowanie metod logiki nieformalnej w badaniu argumentów $\mathrm{w}$ dyskusjach między teistami a ateistami może przybierać rozmaite formy. Rozważmy prosty przykład, przywołując taką oto wypowiedź argumentacyjna: „Codzienna modlitwa służy zdrowiu. Według badań naukowych osoby odmawiające modlitwę chorują rzadziej niż osoby, które się nie modla" ${ }^{21}$. Po standaryzacji argument ten wyglądałby następująco:

(P) Według badań naukowych osoby odmawiające modlitwę chorują rzadziej niż osoby, które się nie modlą.

(K) A zatem: codzienna modlitwa ma właściwości prozdrowotne.

Przypuszczalnie powyższa wypowiedź argumentacyjna mogłaby służyć jako uzasadnienie poglądu, iż ludzie regularnie wykonujący konkretne praktyki religijne odnoszą z wiary w Boga większe korzyści egzystencjalne od innych osób (a co za tym idzie - bardziej „opłaca" się być wierzącym niż niewierzącym). Wykorzystując narzędzia logiki nieformalnej, możemy jednak wskazać na słabości powyższego rozumowania. W tym celu dokonać można ataku na przesłankę (przykładowe pytania krytyczne wobec P: (1) o jakich dokładnie ba-

20 Zob. K. Szymanek, A. Wójcik, K. A. Wieczorek, Sztuka argumentacji..., dz. cyt., s. $57-60$.

21 Tego rodzaju argumentacja, wskazująca na prozdrowotne własności modlitwy, nie należy do rzadkości. Przykładowo na popularnym forum internetowym „wiara. pl” pojawił się swego czasu wpis użytkownika o nicku „zephyr7” następującej treści: „modlący się szybciej zdrowieja, rzadziej chorują - było o tym bodajże w wyborczej. "Amerykańscy naukowcy» zbadali mózgi osób uprawiających modlitwę (buddystów, katolików, Żydów) i odkryli zmianę struktury mózgu u osób modlących się. Badania wskazuja, że modlitwa nie jest obojętna dla zdrowia - reguluje ciśnienie krwi, zapobiega udarom, wzmacnia układ odpornościowy" - pisownia oryginalna, źródło: http:// forum.wiara.pl/viewtopic.php? $\mathrm{p}=590990 \&$ sid=6a413acfaf559b7013b4c72190e $732 \mathrm{c} 7$ (21.01.2017). Warto podkreślić, że w tym argumencie pojawia się dodatkowo wskazanie na wyniki badań medycznych, znane autorowi wypowiedzi z artykułu zamieszczonego, jak można przypuszczać, w Gazecie Wyborczej. 
daniach mówi nadawca komunikatu? (2) czy badania wykonali eksperci w swojej dziedzinie? (3) jakie są opinie innych specjalistów? (4) co właściwie rozumiemy w tym kontekście przez „badania naukowe"? (5) jaka metodą posługiwano się w badaniach? (6) czy zostały przeprowadzone w sposób poprawny? (7) czy nie doszło do błędów w doborze próby? (8) jaką wartość informacyjną mają przeprowadzone badania? (9) jak zdefiniowano w nich pojęcie „modlitwy”? itd.).

W przedstawionym wyżej argumencie z istnienia korelacji statystycznej między zjawiskami wyciagnięto wniosek, iż jedno z nich jest przyczyną drugiego. Można wobec tego postawić również pytania: (1) czy między tymi dwoma zjawiskami rzeczywiście zachodzi korelacja? (2) jeśli tak - czy korelacja nie jest tylko i wyłącznie efektem przypadku? (3) czy na pewno nie istnieje trzecia zmienna, która może mieć wpływ na związek między zachodzącymi zjawiskami? Oczywiście podane tu pytania krytyczne z pewnością nie wyczerpują możliwości, które rysują się przed odbiorcą komunikatu, a dobór kolejnych pytań zależy również od charakteru udzielanych na bieżąco odpowiedzi.

Bywają również argumenty, w których jesteśmy w stanie zaakceptować przesłankę, ale nie godzimy się z tym, iż wspiera ona konkluzję, jak np. w wypowiedzi: „Chrześcijaństwo jest podstawa kulturową zachodniej cywilizacji, dlatego powinniśmy wymusić na Europejczykach respektowanie jego nauczania w sferze etycznej”. W tym przypadku nawet wielu ateistów przyzna, iż chrześcijaństwo odegrało doniosłą rolę w kształtowaniu się naszej cywilizacji. Z drugiej strony wielu chrześcijan (nie wspominając o niewierzących) nie zgodzi się, aby tę okoliczność wykorzystywać do uprawomocnienia praktyk nakazujacych europejskim niechrześcijanom akceptowanie etycznych wskazań chrześcijańskich kościołów ${ }^{22}$.

22 Obecnie podobny problem pojawia się także w kontekście kryzysu migracyjnego, gdy wielu muzułmańskich aktywistów opowiada się za wprowadzaniem w krajach europejskich prawa szariatu. Trzeba jednak dodać, że argumentujący w ten sposób przyjmują w swoich rozumowaniach przesłanki, które znacznie trudniej uzasadnić w naszym kręgu kulturowym, jak np. w wypowiedzi: „Jednego dnia prawo szariatu zostanie wprowadzone także w Polsce, bo wierzymy, że należy usunaćc wszystkie opresyjne reżimy. Jeśli rządzi wami ktoś inny niż Allah, to jest to forma ucisku. Dzię- 
Przeanalizujmy jeszcze inny przykład: „Bóg z pewnością nie istnieje. Tak twierdzi Richard Dawkins, który jest naukowcem. A przecież wiadomo, że naukowcy się nie mylą”. Wpierw dokonajmy standaryzacji argumentu:

(P1) Richard Dawkins twierdzi, że Bóg nie istnieje.

$\left(\mathrm{P}_{2}\right)$ Richard Dawkins jest naukowcem.

$\left(\mathrm{P}_{3}\right)$ Naukowcy się nie myla.

(K) Bóg nie istnieje.

W przypadku tego argumentu mamy do czynienia z kilkoma przesłankami. Rozważmy każdą z nich osobno. W $\mathrm{P}_{1}$ mamy do czynienia ze stwierdzeniem oczywistym. Zgadamy się, że Dawkins twierdzi, iż Bóg nie istnieje (chyba że wiemy, iż w tej kwestii brytyjski biolog zmienił swoje zdanie). Z drugiej strony niekoniecznie musimy zgodzić się z tym, iż skoro Dawkins twierdzi, że Bóg nie istnieje, to Bóg rzeczywiście nie istnieje (byłby to wtedy przykład argumentu z autorytetu, którego wartość byłaby tutaj zasadniczo niewielka). $\mathrm{W}_{2}$ sprawa wymaga nieco bardziej subtelnych analiz. Dawkins jako biolog z pewnościa jest naukowcem, biorąc pod uwage przyjęte obecnie standardy. Dawkins jest jednak naukowcem zajmującym się biologia, a nie kwestiami z pogranicza nauk (również takich jak fizyka czy chemia), filozofii czy religioznawstwa, które podejmują zagadnienie Boga. Czy w związku z tym jego zdanie w kwestii istnienia Absolutu może być bardziej wiarygodne niż zdanie laika? Oczywiście mamy prawo powiedzieć, że o istnieniu Boga również przedstawiciele wspominanych dyscyplin nie wypowiadają się w sposób dostatecznie jasny i przekonujący, co nie oznacza jeszcze, że monopol w tej dziedzinie przysługiwać będzie automatycznie biologom. Gdyby $\mathrm{P}_{2}$ została rozbudowana (np. o wyjaśnienie, jak Dawkins argumentu-

ki naszej polityce i ten wasz reżim zostanie usunięty, a ludzie będą szczęśliwsi”. Autorem tej wypowiedzi jest imam Anjem Choudary; dla programu „Fakty TVN” rozmowę przeprowadził Maciej Woroch. Źródło: http://fakty.tvn24.pl/fakty-ekstra,52/ imam-choudary-prawo-szariatu-zostanie-wprowadzone-takze-w-polsce, 513212.html (15.02.2017). 
je na rzecz ateizmu, dlaczego jako biologowi przysługuje mu prawo do rzetelnego wypowiadania się o istnieniu Boga itd.), to jej wartość z pewnością mogłaby znacząco wzrosnąć. W takiej postaci, w jakiej została przedstawiona, wydaje się jednak mało przekonująca.

Cały argument najłatwiej byłoby obalić poprzez atak na $\mathrm{P}_{3}$ (z racji tego, iż stanowi tutaj bezpośrednie przejście do konkluzji). Naukowcy - jak to z ludźmi bywa - z pewnościa sa omylni. Choć zapewne bywają ekspertami w swojej dziedzinie, niekoniecznie musza znać odpowiedź na pytanie, czy Bóg istnieje. Ponadto z $\mathrm{P}_{3}$ jest jeszcze przynajmniej jeden problem. Otóż żyją naukowcy, którzy uważaja, że Bóg istnieje. Czy w takim razie się mylą? A może po prostu nie sa naukowcami?

Konkluzja „Bóg nie istnieje” oczywiście nie musi być fałszywa. Fakt, że można podważyć przesłanki zastosowane w powyższym rozumowaniu, nie oznacza, że brak innych racji, które przesądzałyby na rzecz ateizmu (lub czyniły go np. bardziej wiarygodna opcja światopoglądową niż teizm). W pewnym sensie podobnie sprawa ma się z teizmem. Nie każdy podważony argument zawierający konkluzję „Bóg istnieje” od razu przesądza na korzyść ateizmu. Sprawa jest tutaj dodatkowo skomplikowana, ponieważ zagadnienia pojawiające się w dyskusjach między teistami i ateistami często są wplątane $\mathrm{w}$ sieć zależności z zagadnieniami z zakresu nauk przyrodniczych, których znajomości zazwyczaj nie opanował w dostatecznym stopniu każdy z dyskutantów.

I tak np. dla wypowiedzi (odwołującej się tutaj do nauk matematyczno-przyrodniczych): „Bóg istnieje, poniewaź świat nie może być dziełem przypadku" ${ }^{23}$ możemy znaleźć kontrargumenty mówiące, że znany nam świat może być efektem przypadku. W tak trudnych do rozstrzygnięcia sytuacjach ogromną rolę odgrywa wiedza, która posiadają dyskutujacy, w zakresie dziedzin, do osiagnięć których się odwołują (w tym wypadku będą to matematyka, fizyka i astronomia, biologia itp.), i umiejętność ich analizy przy użyciu narzędzi

23 Zob. np. wpis na blogu internetowym „Młot na ateistów” z dnia 27.12.2012 pt. Przypadek? Pytanie o powstanie świata, http://mlot.blogspot.com/2012/12/przypadek-pytanie-o-powstanie-swiata.html (22.01.2017). 
metodologicznych (np. rozwiązanie problemu wyjaśniania naukowego, zagadnienie naturalizmu i redukcjonizmu itd.). Rozwiązanie problemu, czy Bóg istnieje, czy też nie istnieje, wymaga często odwoływania się do różnych dyscyplin (w zależności od tego, jaki argument jest formułowany), a konkluzje poszczególnych wypowiedzi niekoniecznie muszą przesądzać o definitywnym rozstrzygnięciu sporu między teistami i ateistami ${ }^{24}$. Problemem wielu dyskusji jest to, że osobiste przekonania w przedmiocie sporu nie zawsze sa tożsame ze stanem wiedzy w danym zagadnieniu, co utrudnia rzetelna dyskusję. Gdy na domiar złego w dyskusji wykazuje się brak kompetencji w interpretacji faktów naukowych (interpretacji - dodajmy - często bardzo zróżnicowanych i niejednoznacznych), dostrzec można, w jak trudnym obszarze znaleźli się polemizujacy ${ }^{25}$.

Częstym mankamentem polemik między teistami a ateistami jest nie tylko nieznajomość osiagnięć nauk matematyczno-przyrodniczych i narzędzi metodologicznych u dyskutantów, ale również podstaw światopoglądowych atakowanej strony. Rzecz tyczy się zarówno teistów, jak i ateistów. Za przykład niech posłuży wypowiedź: „Księga Rodzaju zawiera nieprawdziwe informacje, ponieważ jednoznacznie jest w niej napisane, że świat został stworzony w sześć dni”. Oczywiście wiemy dziś, że wszechświat powstawał przynajmniej trzynaście miliardów lat. Z drugiej jednak strony moglibyśmy przyjąć, że Księga Rodzaju mija się z prawda, dopiero wówczas, gdyby aspirowała do miana naukowego podręcznika o dziejach kosmosu. Nie możemy być do końca pewni, jakie cele przyświecały jej autorom, ale biorąc pod uwagę fakt, iż opis stworzenia ma formę hebrajskiej poezji, można rozważyć takie podejście do tych konkretnych fragmentów o sześciu dniach, jakie stosuje się w przypadku tekstów poetyckich

24 Poszczególne argumenty mogą natomiast zwiększać wiarygodność wysuwanych twierdzeń. Przykładowo: im więcej argumentów na rzecz ateizmu odwołujących się do nauki współczesnej, tym bardziej może wydać się on poglądem racjonalnym, zgodnym ze stanem współczesnej wiedzy.

${ }_{25}$ Istotna jest również świadomość istnienia sieci relacji między nauką a filozofia. „Nie ma czegoś takiego jak nauka wolna od filozofii, jest to tylko nauka, która jest uprawiana bez rozważania znajdujących się u jej podstaw założeń filozoficznych” - D. Dennett, Dźwignie wyobraźni i inne narzędzia do myślenia, tłum. Ł. Kurek, Kraków 2015, s. 32 . 
(z nastawieniem, iż posiadają one przede wszystkim sens przenośny). Również okoliczność, iż przez stulecia w chrześcijaństwie interpretowano poemat o stworzeniu najczęściej w sposób dosłowny, nie świadczy jeszcze o tym, że Księga Rodzaju w opisie stworzenia próbuje powiedzieć coś na temat początku świata tak, jak czynią to dzisiejsze nauki (choć możemy zastanawiać się, czy dzisiejszy sposób interpretowania tekstów poetyckich jest choć zbliżony do dawniejszych metod odbioru utworów literackich). Oczywiście wskazana problematyczność nie neguje automatycznie znaczenia innych argumentów krytycznych wysuwanych przez historyków piśmiennictwa chrześcijańskiego wobec tekstów biblijnych ${ }^{26}$. Pokazuje jednak, że należy dobrze poznać podstawy ideowe własnego światopoglądu i światopoglądu dyskutanta, jeśli chcemy uniknaćc mało merytorycznej dyskusji, opierającej się na domysłach i niesprawdzonych informacjach (być może więc warto byłoby przed podjęciem rozmowy postawić sobie samemu pytanie, w jakim stopniu znam podstawy teoretyczne światopoglądu religijnego/ateistycznego mojego rozmówcy).

W sporach między teistami a ateistami częstą praktyką jest posługiwanie się stereotypami (np. „ateiści to komuniści i lewacy”27), nieprecyzyjnymi sformułowaniami i uogólnieniami (np. „katolicy tuszują zjawiska pedofilii”; „ateiści odpowiadaja za zbrodnie przeciwko ludzkości”) czy wręcz obraźliwymi stwierdzeniami (np. „poglądy katolików to ciemnogród”), które z pewnością nie przydaja ich autorom powagi, choć bywaja podchwytywane przez obserwatorów i uczestników dyskusji. Dzięki wykorzystaniu metod logiki nieformalnej łatwiej podważać wartość tego typu wypowiedzi. Jest to o tyle istotne, że w społecznym odbiorze liczy się często efektowność, a nie efektywność wypowiedzi. Mając to na względzie, skuteczna obrona przed nieuczciwymi sztuczkami erystycznymi może okazać się umiejętnością nie mniej istotną niż budowanie własnych rzetelnych argumentów.

26 Zob. np. B. Ehrman, Przeinaczanie Jezusa. Kto i dlaczego zmieniat Biblię, tłum. M. Chowaniec, Warszawa 2009.

27 Zob. np. R. Blackford, U. Schüklenk, 50 mitów o ateizmie, tłum. P. J. Szwajcer, Stare Groszki 2014, s. 127-133. 
W sytuacjach problemowych, gdy trudno jednoznacznie ocenić wysuwany argument, cenne jest korzystanie z tzw. zasady życzliwości, która zaleca interpretować wypowiedzi oponenta w możliwie przychylny dla niego sposób (jak na gruncie prawnym funkcjonuje zasada domniemanej niewinności, tak w sztuce dyskusji przyjmuje się, że dopóki nie istnieją poważne powody by sądzić, iż oponent się myli, jego wypowiedzi traktujemy tak, jakby nie były błędne). Tego rodzaju postępowanie chroni także przed popadnięciem w tzw. argumentację słomianej kukły, która polega na tworzeniu zdeformowanego obrazu poglądów oponenta (a często także przypisywaniu mu słów, których nie wypowiedział) celem ich obalenia przez zastosowanie własnej argumentacji. „Ustawianie” dyskutanta w perspektywie, w której łatwo będzie podważyć przypisywane mu poglądy, jest nieuczciwą techniką erystyczna, pojawiająca się niestety również w dyskusjach światopoglądowych (np. „Ponieważ jesteś katolikiem, to z pewnością nie wierzysz w ewolucję gatunków. Jesteś zacofany, a to znaczy, że nie powinieneś uczyć w szkołach wyższych, gdzie zjawisko ewolucji biologicznej od dawna uznawane jest za fakt”).

Nie należy przy tym zapominać o działaniu mechanizmów psychicznych, które mogą zniekształcać osąd dyskutujących. Biorąc pod uwagę, że nasze życie umysłowe w dużej mierze bazuje na procesach intuicyjnych i emocjonalnych ${ }^{28}$, nie zawsze jesteśmy w stanie formułować dobre argumenty, a także w sposób rzetelny oceniać poglądy oponenta. Przedmiotem dyskusji między teistą a ateistą może być np. zagadnienie, które wymaga zdolności myślenia statystycznego (jak chociażby problem powstania i ewolucji życia). Tymczasem gdy dokonujemy ocen przypadkowości zdarzeń autentycznie losowych, często ulegamy skłonności do myślenia przyczynowo-skutkowego, czym narażamy się na poważne błędy ${ }^{29}$. W rozumowaniach dotyczących przyczyn jesteśmy szczególnie narażeni na pomyłki (gdy np. myli się związek przyczynowo-skutkowy z powodem, dla którego dyskutant w coś wierzy, jak chociażby w wypowiedzi: „Bóg istnieje, ponieważ odkąd zacząłem wierzyć, jestem człowiekiem szczęśliw-

28 Zob. D. Kahneman, Pułapki myślenia..., dz. cyt., s. 30-143.

29 D. Kahneman, Pułapki myślenia..., dz. cyt., s. 225-236. 
szym”; albo kiedy zakłada się, iż zjawisko ma tylko jedną przyczynę: „Gdyby Janek wierzył w Pana Boga, nie popełniłby samobójstwa”). Stosowanie heurystyk, czyli uproszczonych reguł wnioskowania, odbywa się zwykle w sposób nieświadomy, dlatego istotne jest, aby przynajmniej zdawać sobie sprawę, w jakich przypadkach dyskutujący mogą być narażeni na popełnianie błędów.

\section{Podsumowanie}

Ponieważ użyteczność metod logiki nieformalnej w badaniu potocznych argumentów między teistami a ateistami wydaje się znacząca (choć z racji objętości artykułu ograniczono się tutaj do przedstawienia zaledwie kilkunastu przykładowych wypowiedzi), kontynuowanie badań w tym zakresie mogłoby przynieść bardzo pożądane owoce. Wiele argumentów wysuwanych w tych dyskusjach ma charakter mało merytoryczny i bazuje na uproszczonych regułach wnioskowania, co widoczne jest w momencie, gdy poddajemy je analizie przy użyciu narzędzi, których dostarczają logicy i psychologowie społeczni. Prowadzenie tego rodzaju badań mogłoby służyć nie tylko ocenie poszczególnych wypowiedzi, ale również uwrażliwiać dyskutujących na konieczność budowania bardziej przekonujacych argumentów.

Aby jednak kultura i jakość merytoryczna wypowiedzi dyskusyjnych wzrosła, konieczne jest spełnienie kilku warunków. Problem istnienia/nieistnienia Boga i sposobu życia teistów oraz ateistów jest na tyle złożony, że wymaga od dyskutujacych nie tylko znacznej wiedzy z zakresu kilku dyscyplin naukowych, ale również olbrzymiej pokory poznawczej i skromności wobec stawianych celów dyskusji. Otwartość na krytykę i modyfikację własnego punktu widzenia sa tutaj nie mniej cenne niż życzliwy stosunek do oponenta, w którym przejawia się brak uprzedzeń oraz otwartość na dialog. W związku z tym, iż częstym powodem nieporozumień między teistami i ateistami jest obustronna nieznajomość teoretycznych podstaw własnego i krytykowanego światopoglądu, istotne jest odpowiednie przygotowanie merytoryczne do dyskusji. Budowanie rzetelnych argumentów (a co za tym idzie - unikanie stosowania nieuczciwych chwytów ery- 
stycznych) i umiejętność oceny cudzych wypowiedzi nie czyni jeszcze dyskutujących ekspertami w danej dziedzinie. Warto mieć także świadomość, że jako istoty biologiczne jesteśmy uwarunkowani mechanizmami psychicznymi, z których nie zawsze zdajemy sobie sprawę, a które mają wpływ na to, jak argumentujemy i jak oceniamy argumentację oponenta.

W dyskusjach między teistami a ateistami pojawiają się różne wypowiedzi argumentacyjne. Wiele z nich wymaga bardzo drobiazgowych analiz, których nie sposób dokonać, odwołując się wyłącznie do języka potocznego. Często można spotkać się również z twierdzeniem, że ateizm winien być postawą wyjśsiową wobec problemu istnienia/nieistnienia Boga, a konieczność dostarczenia argumentu na rzecz teizmu leży po stronie osób wierzących. Znany powszechnie argument teisty: „Nie potrafisz udowodnić, że Bóg nie istnieje, a zatem On istnieje" traciłby wtedy swoją moc na podobnej zasadzie, jak argument: „Nie potrafisz udowodnić, że nie istnieją krasnoludki, a więc one istnieją" Czy można wnosić, że istnieją krasnoludki (albo smoki, syreny itd.), tylko dlatego że nikt nie może udowodnić, że nie istnieją? Oczywiście nie rozstrzyga to sporu, jednak warto mieć świadomość, że tego rodzaju wypowiedzi w dużej mierze moga warunkować przebieg dyskusji, skazując teistę na potrzebę wykazania się większą sprawnością w budowaniu argumentów na rzecz swojego światopoglądu.

Spory między teistami i ateistami rozgrywają się także na polu zagadnień związanych z etyką i życiem społecznym (problem aborcji, stosunek do życia seksualnego itd.). Umiejętność wykorzystania narzędzi logiki nieformalnej w takich dyskusjach mogłaby okazać się dużym atutem i mieć znaczenie np. dla kształtu konkretnych rozporządzeń prawnych danego kraju. Interesujace byłoby również przebadanie, czy (i jak) podzielany światopogląd oddziałuje na stosunek ateistów i teistów do poszczególnych problemów etyczno-społecznych.

Perspektywy badawcze wydaja się zatem rozległe, a te wymienione z pewnością nie wyczerpują ich listy. Dodatkowym atutem byłaby z pewnościa popularyzacja osiagniętych wyników, dająca wgląd w problematykę wszystkim osobom zainteresowanym prowadzeniem dyskusji o charakterze światopoglądowym. 


\section{Summary}

\section{Informal logic methods in the study of arguments between theists and atheists}

This paper argues that methods used in informal logic (sometimes called Critical Thinking) could be helpful in examining the arguments in discussions between theists and atheists. Application of the techniques of informal logic could reveal the substantive value of many commonly shared views about theism (and theists) and atheism (and atheists). The utility of applying informal logic methods has illustrated by several examples.

Keywords: argumentation, informal logic, atheism, theism, critical thinking

\section{Bibliografia}

Ajdukiewicz K., Zarys logiki, Warszawa 1955.

Blackford R., Schüklenk U., 50 mitów o ateizmie, tłum. P. J. Szwajcer, Stare Groszki 2014.

Blair J. A., Informal Logic and Logic, „Studies in Logic, Grammar and Rhetoric" 16 (2009) no. 29 , s. 47-67.

Budzyńska K. et al., The Polish School of Argumentation: A Manifesto, „Argumentation" 28 (2014), s. 267-282.

Buss D. M., Psychologia ewolucyjna, tłum. M. Orski, Gdańsk 2001.

Cialdini R. B., Wywieranie wpływu na ludzi. Teoria i praktyka, tłum. B. Wojcieszke, Gdańsk 2013.

Dennett D., Dźwignie wyobraźni i inne narzędzia do myślenia, tłum. Ł. Kurek, Kraków 2015.

Ehrman B., Przeinaczanie Jezusa. Kto i dlaczego zmieniat Biblię, tłum. M. Chowaniec, Warszawa 2009.

Gardenfors P., Jak Homo stał się sapiens. O ewolucji myślenia, tłum. T. Pańkowski, Warszawa 2010.

Hand D. J., Zasada nieprawdopodobieństwa. Dlaczego codziennie zdarzaja się cuda i zbiegi okoliczności, tłum. J. Winiarski, Warszawa 2015.

Kahneman D., Pułapki myślenia. O myśleniu szybkim $i$ wolnym, tłum. P. Szymczak, Poznań 2012. 
Koszowy M., Budzyńska K., Strategie retoryczne, techniki komunikacyjno-poznawcze, błędy i sofizmaty, Warszawa 2015.

Przypadek? Pytanie o powstanie świata, http://mlot.blogspot.com/2012/12/ przypadek-pytanie-o-powstanie-swiata.html (22.01.2017).

Rossetti L., Raport o „logice nieformalnej”, w: Między prawda i norma a błędem, red. E. Żarnecka-Biały, Kraków 1997.

Ruch Palikota składa wniosek o usunięcie krzyża z sali sejmowej, https:// ekai.pl/ruch-palikota-sklada-wniosek-o-usuniecie-krzyza-z-sali-sejmowej (22.11.2017).

Schopenhauer A., Erystyka, czyli sztuka prowadzenia sporów, tłum. J. Lorenowicz, Kraków 2010.

Szymanek K., Argument z podobieństwa, Katowice 2008.

Szymanek K., Sztuka argumentacji. Stownik terminologiczny, Warszawa 2004.

Szymanek K., Wójcik A., Wieczorek K. A., Sztuka argumentacji. Ćwiczenia w badaniu argumentów, Warszawa 2005.

Tavris C., Aronson E., Bładza wszyscy (ale nie ja), tłum. A. Nowak, Sopot 2008.

Tokarz M., Argumentacja, perswazja, manipulacja. Wykłady z teorii komunikacji, Gdańsk 2006.

Wieczorek K. A., Argumenty równi pochytej. Analiza z perspektywy logiki nieformalnej, Katowice 2013. 